\title{
USE OF INTERNET IN THE JOB SEARCH PROCESS: GENDER PERSPECTIVE
}

\author{
Marina Savković, \\ Slavko Alčaković, \\ Nemanja Đorđić
}

Singidunum University, 32 Danijelova Street, Belgrade, Serbia

\section{Correspondence:}

Marina Savković

e-mail:

msavkovic@singidunum.ac.rs

\begin{abstract}
:
Bearing in mind the slowdown of the global economy and modest potential for job creation, job seekers are in a vulnerable position. This particularly applies to the young people who are looking for the first employment. That has led to a growing interest in analyzing the ways in which candidates look for a job, and effectiveness of certain tools. In the last fifteen years, the Internet has been widely accepted as a job search tool. Therefore, the authors have placed special emphasis on the Internet job search activities of young people in Serbia and possible gender based differences. The results have shown that there are no gender-based differences in behaviour of young job seekers. In addition, it can be concluded that the Internet job search activities are very intensive and recognized as one of the main job search tools, with the international trends in behaviour of job seekers.
\end{abstract}

Key words:

job search activities, the Internet, young job seekers, job search intensity, gender-based differences in behaviour of job seekers.

\section{INTRODUCTION}

Young people are faced with difficulties at labor market. That particularly refers to the job search period, possibilities of finding stable employment, unemployment and poverty risks etc. (Arandarenko, 2011; Krstić et al., 2010; Jovičić \& Lazarević, 2014; European Commission, 2012). As a consequence of labor market flexibilization and latest international economic crisis, young people face the possibility of finding non-standard employment, long-term job search and labor market exclusion (European Commission, 2012; O'Reilly et al., 2015). These are some of the reasons for the growing scientific and research interest in job search activities, its intensity and effectiveness.

On the other hand, the Internet has become a very important channel for job search activities (Kuhn \& Skuterud, 2002; Van Roy, 2003; Kudlyak \& Romero, 2013). Due to its rapid expansion, the intensity of Internet job activities among job seekers tripled in the period from 1998 to 2009 (Kuhn \& Mansour, 2011). On the other hand, Internet job matching platforms have emerged over the past fifteen years, and have become an important element of modern labour markets (Levin, 2011). The Internet has led to reallocation of effort among various job search activities (Stevenson, 
2008), so the Internet resource has become the main source of information used by job seekers during the job search process (Van Roy, 2003; Stevenson, 2008; Beard, 2010; Kudlyak \& Romero, 2013).

Internet use in job search process and its effect on employment outcomes have also changed over time. Although job search was first considered ineffective, recent findings suggest that it has become an effective tool for finding a job, so it reduces individual workers' unemployment duration (Kuhn \& Mansour, 2011; Suvankulov \& Chi Keung Lau, 2012). Also, job seekers who use Internet for search activities had positive employment or reemployment outcomes, compared to general job seekers population (Suvankulov \& Chi Keung Lau, 2012). The Internet also has positive effects on general labour market activity. Some analyses have shown that the Internet use keeps job seekers active and reduces the possibility of job search discouragement by over 50 percent (Beard et al., 2010).

\section{INTERNET USE IN GENDER PERSPECTIVE}

Bearing in mind gender based differences in labor market outcomes (Arandarenko, 2011; European Commission, 2012), gender perspective of Internet use in this case is important. Gender gap in the Internet use was evident in 1990s, but it decreased and almost disappeared in 2000s (Ono \& Zavodny, 2002).

The main research question of this paper is: „Is there any gender-based gap in the Internet job search activities among the young job seekers in Serbia?" It was mainly related to Internet job search intensity and use of different Internet contents in job search process (online job boards, employers' websites visits, professional and other social networks, job search clubs, online job adverticements etc.). We were also interested in the devices job seekers use for Internet job search. Our hipothesis is defined in the following way: There are no statistically significant gender-based differences in Internet job search activities.

\section{METHODOLOGY}

Research method used in this case was the online survey. Respondents were participants of a career fair held at Singidunum University on March 4th, 2016. They were predominately graduates who uploaded their CV in the career fair database. They were asked to give answers to different questions related to several aspects of the job search process. Out of 173 respodents, 121 were women and 52 man, which aproximately represents gender struc- ture of visitors attending this career fair. Also, over 98\% of respondents were younger than 35.62. Furthermore, $8 \%$ of them were aged between $15-24$, years old, since $35.7 \%$ were in the age group of 24-35.

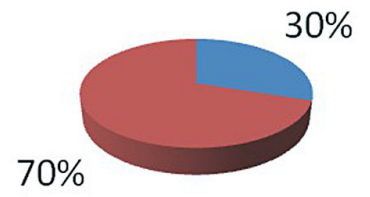

Men

Women

Figure 1. Sample structure

Job search activities could be generally analized through job search effort and intensity, job search strategies, preparatory and active job search behavior, formal and informal job sources, specific job search behavior job search quality, job search dynamics, and job search persistence etc. (Van Hoye, 2014, p. 2). We were predominantly interested in the intensity of job search activities. The areas of job search covered are:

- Internet job search activities,

- Devices used for Internet job search.

We used ANOVA to compare potential gender-based differences within the sample, related to job search activities. Independent variable was gender, since dependent variables were: "I use social networks (Linkedin, Twitter, Facebook etc.) in the job search process", "I use online job boards", "I visit employers websites", "I network with other job seekers using specialized websites". The respondents were asked to grade their specific Internet activity on 1-5 scale (where „1“ stands for "never“ and 5 stands for „very often“).

We also wanted to find out something about the intensity and possible gender-based differences of devices used for Internet job search. ANOVA was also used in this case, where independent variable was gender, while dependent variables were: "I use laptop when search for job related information", "I use desktop computer when search for job related information", "I use mobile phone when search for job related information", "I use tablet computer when search for job related information" and "I use other devices when search for job related information". The questionnaire included other questions related to non-Internet job search activities (Use of HR agences services, Career fairs visits, use of university career center services, use of National Employment Office services etc.), job search strategy, salary and other relevant labor market preferences, but it will not be analyzed in detail, bearing in mind the specific research topic. 


\section{RESULTS AND DISCUSSION}

According to the results in Table 1, there are no differences in general Internet use for job search activities. More than $95 \%$ of respondents actively use Internet in job search process, which is in accordance with the international trends of job seekers behaviour.

\begin{tabular}{ccccc}
\hline \multirow{2}{*}{ Gender of respondents } & \multicolumn{4}{c}{ Answers } \\
\cline { 2 - 5 } & Yes & $\%$ & No & $\%$ \\
\hline Man & 50 & 96.15 & 2 & 3.85 \\
\hline Women & 115 & 95.04 & 6 & 4.96 \\
\hline
\end{tabular}

Table 1. Question: Do you use Internet services in the job search process?

The results show that there is no statistically significant gender-based difference in intensity of the Internet job search activities in any of the cases (Table 2). The use of online job boards (4.16) and employers websites visits (3.86) were the most intensive Internet job search activities for all the respondents. Networking with other job seekers was not recognized as an interesting job search activity by any group (2.29 in average).

\begin{tabular}{|c|c|c|c|c|}
\hline Questions & Gender & Mean & SD & $\mathrm{N}$ \\
\hline \multirow{3}{*}{$\begin{array}{l}\text { I use social net- } \\
\text { works (Linkedin, } \\
\text { Twitter, Facebook } \\
\text { etc.) in the job } \\
\text { search process }\end{array}$} & Male & 3.02 & 1.435 & 51 \\
\hline & Female & 3.36 & $1 ., 448$ & 120 \\
\hline & Total & 3.26 & 1.448 & 171 \\
\hline \multirow{3}{*}{$\begin{array}{l}\text { I use online job } \\
\text { boards }\end{array}$} & Male & 4.25 & 1.214 & 51 \\
\hline & Female & 4.12 & 1.204 & 120 \\
\hline & Total & 4.16 & 1.205 & 171 \\
\hline \multirow{3}{*}{$\begin{array}{l}\text { I visit employers } \\
\text { websites }\end{array}$} & Male & 3.67 & 1.052 & 51 \\
\hline & Female & 3.94 & 1.19 & 120 \\
\hline & Total & 3.86 & 1.155 & 171 \\
\hline \multirow{3}{*}{$\begin{array}{l}\text { I network with } \\
\text { other job seekers } \\
\text { using specialized } \\
\text { websites }\end{array}$} & Male & 2.25 & 1.278 & 51 \\
\hline & Female & 2.3 & 1.274 & 120 \\
\hline & Total & 2.29 & 1.272 & 171 \\
\hline
\end{tabular}

$S D$ - standard deviation; $N$ - Number of respondents

Table 2. Question: Intensity of different ways of Internet job search
It is interesting that online social networks are not used at all among $28.2 \%$ of the respondents. Linkedin was recognized as the best social network for job search activities (55.8\%), Facebook was favored by $13,6 \%$ of the respondents, while Twitter was not recognized at all in this sense (no respondent recognized it as the best social network for job search).

Since we also surveyed intensity of non-internet job search activities, we can mention that the differences were recognized only for three job search activities: 1 . Use of HR agencies services $(F(1,170)=3,944, p=0.05), 2$. Career fairs visits $(F(1,170)=9,497, p<0.05)$, and 3 . Use of university career center services $(F(1,170)=5,092, p<0.05)$. Women are more engaged in all of the mentioned activities, which is consistent with the sample structure and gender structure of career fair visitors.

\begin{tabular}{|c|c|c|c|c|}
\hline Questions & Gender & Mean & Std. Dev. & $\mathrm{N}$ \\
\hline \multirow{3}{*}{$\begin{array}{l}\text { I use laptop when } \\
\text { search for job re- } \\
\text { lated information }\end{array}$} & Male & 3.55 & 1.646 & 49 \\
\hline & Female & 4.17 & 1.354 & 118 \\
\hline & Total & 3.99 & 1.468 & 167 \\
\hline \multirow{3}{*}{$\begin{array}{l}\text { I use desktop com- } \\
\text { puter when search } \\
\text { for job related } \\
\text { information }\end{array}$} & Male & 3.33 & 1.688 & 49 \\
\hline & Female & 2.75 & 1.659 & 118 \\
\hline & Total & 2.92 & 1.683 & 167 \\
\hline \multirow{3}{*}{$\begin{array}{l}\text { I use mobile phone } \\
\text { when search for job } \\
\text { related information }\end{array}$} & Male & 3.18 & 1.523 & 49 \\
\hline & Female & 3.43 & 1.38 & 118 \\
\hline & Total & 3.36 & 1.424 & 167 \\
\hline \multirow{3}{*}{$\begin{array}{l}\text { I use tablet com- } \\
\text { puter when search } \\
\text { for job related } \\
\text { information }\end{array}$} & Male & 1.53 & 1.082 & 49 \\
\hline & Female & 1.74 & 1.317 & 118 \\
\hline & Total & 1.68 & 1.253 & 167 \\
\hline \multirow{3}{*}{$\begin{array}{l}\text { I use other devices } \\
\text { when search for job } \\
\text { related information }\end{array}$} & Male & 1.51 & 0.845 & 49 \\
\hline & Female & 1.89 & 1.407 & 118 \\
\hline & Total & 1.78 & 1.277 & 167 \\
\hline
\end{tabular}

$S D$ - standard deviation; $N$ - Number of respondents

Table 3. Devices used for Internet job search 
Devices used for Internet job search activities were also an area of our research interest. Differences were found only in the cases of laptop $(\mathrm{F}(1,170)=8,825$, $\mathrm{p}<0.05)$ and desktop computer use $(\mathrm{F}(1,170)=6,007$, $\mathrm{p}<0.05)$. Female respondents use laptop more often than male respondents. On the other side, male respondents use desktop computers more intensively than female when looking for job related information. The most interesting devices for job search are laptops (3.99) and mobile phones (3.36). In most of the cases, the tablet computer was not recognized as an Internet job search device (1.68).

\section{CONCLUSION}

Our research results show that the Internet as a job search tool is used almost by all young job seekers in Serbia. They actively use different Internet platforms and contents in the job search process more often than non-Internet job search activities, which is similar to previous scientific findings in this field. We could observe significant differences in intensity of different Internet job search activities. Online job boards were most attractive to the respondents, while networking with other job seekers was not recognized as a regular job search activity. Internet use has became broadly accepted both among men and women, which is also relevant for job seekers behavior literature.

We could not find statistically significant difference in Internet use in the job search process among male and female respondents. Also, intensity of Internet job search activities is very similar. Some differences were recognized when we analyzed devices used for job search activities and non-Internet job search activities. Bearing in mind all of the mentioned, we can say that our research hypothesis is confirmed.

Some future analyses could be focused on gender based differences of older groups of job seekers. Also, job search strategies, general job search intensity could be correlated with Internet job search activities and possible gender based differences. Finally, effectiveness of every Internet job search activity should be evaluated in the perspective of employment outcomes, since some of the activities were widely accepted (Use of online job boards) and some were not recognized at all (Networking with other job seekers).

\section{REFERENCES}

Arandarenko, M. (2011). Tržište rada u Srbiji - Trendovi, institucije, politike. Beograd: Centar za izdavačku delatnost Ekonomskog fakulteta u Beogradu.
Beard, T. R., Ford, S. G., \& Richard P. S. (2010).Internet Use and Job Search, Phoenix Center Policy Paper Number 39. Phoenix Center for Advanced Legal and Economic Public Policy Studies.

Levin, D. J. (2011). The Economics of Internet Markets, NBER Working Paper No. 16852, Natonal Bureau of Economic Research: Cambridge. Retrieved March 29, from: http://www.nber.org/papers/ w16852.pdf

European Commission. (2012). Moving Youth into Employment, Communication from the Commission to the European Parliament, The Council. Brussels: The European Economic and Social Committee of the Regions.

Jovičić, J., \& Lazarević, M. (2014). Active Measures of Employment in Serbia: More Social Assistance than Anything Else, policy brief. Belgrade: Belgrade Fund for Political Excellence.

Krstić, G. (2010). Položaj ranjivih grupa na tržištu rada Srbije. Beograd: Fond za razvoj ekonomske nauke, Razvojni program UN Srbija.

Kudlyak, M., \& Romero, J. (2013). Job Search Behavior: Lessons from Online Job Search, Economic Brief, April 2013, EB13-04. Retrieved March 2, 2016, from: https://www.richmondfed.org/ /media/ richmondfedorg/publications/research/economic brief/2013/pdf/eb_13-04.pdf

Kuhn, P.J., Mansour, H. (2011). Is internet job search still ineffective?, Discussion paper series // Forschungsinstitut zur Zukunft der Arbeit, No. 5955, Retrieved February 28, from http://nbn-resolving.de/ urn:nbn:de:101:1-201109297545

Kuhn, P., Skuterud, M. (2002). Internet Job Search and Unemployment Durations, IZA Discussion paper series, No. 613

Van Rooy, D. L., Alonso, A., \& Zachary, F. (2003) In With the New, Out With the Old: Has the Technological Revolution Eliminated the Traditional Job Search Process, International Journal of Selection and Assessment, 11(2/3), 170-175. DOI:10.1111/14682389.00240

Ono, H., Zavodni, M. (2002). Gender and the Internet, Working Paper 2002-10, Federal Reserve Bank of Atlanta. Retrieved March 26, 2016, from https:// www.frbatlanta.org/-/media/Documents/filelegacydocs/wp0210.pdf

O'Reilly, Jacqueline et al. (2015). Five Characteristics of Youth Unemployment in Europe: Flexibility, Education, Migration, Family Legacies, and EU Policy. January-March 2015:1-19, SAGE Open, Retrieved December 17, 2015, from: http://sgo.sagepub.com/ content/spsgo/5/1/2158244015574962.full.pdf 
Stevenson, B. (2008). The Internet and Job Search, Working Paper 13886, National Bureau of Economic Research, Cambridge. Retrieved March 24, 2016, from http://www.nber.org/papers/w13886

Suvankulov, F., \& Chi Keung Lau, M. (2012). Job search on the internet and its outcome, Internet Research, May 2012. DOI:10.1108/10662241211235662
Van Hoye, G.(2014). Job Search Behavior as a Multidimensional Construct: A Review of Different Job Search Behaviors and Sources, in U.C. Klehe \& E.A.J. van Hooft (Eds.), Oxford Handbook of Job Loss and Job Search. New York: Oxford University Press. 